\title{
A Zenker-diverticulumok transcervicalis és transoralis sebészi kezelésének összehasonlító vizsgálata, rövid és hosszú távú eredmények
}

\author{
Andrási László dr. ${ }^{1}$ - Ábrahám Szabolcs dr. ${ }^{1}$ - Simonka Zsolt dr. ${ }^{1}$ \\ Paszt Attila dr. ${ }^{1}$ - Rovó László dr. ${ }^{2}$. Lázár György dr. ${ }^{1}$ \\ ${ }^{1}$ Szegedi Tudományegyetem, Általános Orvostudományi Kar, Sebészeti Klinika, Szeged \\ ${ }^{2}$ Szegedi Tudományegyetem, Általános Orvostudományi Kar, \\ Fül-Orr-Gégészeti és Fej-Nyaksebészeti Klinika, Szeged
}

\begin{abstract}
Bevezetés és célkitüzés: Vizsgálatunkban a Zenker-diverticulum nyitott (transcervicalis diverticulectomia, cricomyotomia) és transoralis (transoralis stapler diverticulostomia) mútéti kezelésével szerzett tapasztalatainkat mutatjuk be. Módszer: 2006. január 1. és 2016. december 31. között 29 beteget kezeltünk panaszokat okozó Zenker-diverticulummal. Összesen 29 mútét történt, 13 esetben transcervicalis, 16 alkalommal transoralis mútétet végeztünk. Összehasonlítottuk az eltérő megközelítésú sebészi kezelések perioperatív és hosszú távú eredményeit.

Eredmények: A betegek átlagosan 31 hónapos panaszos időszakot követően kerültek mútétre. A vezető tünet mindkét csoportban a súlyos dysphagia és a súlyos regurgitatio volt. Intraoperatív szövődményt nem észleltünk. Egy beteg vérzés miatt reoperációra került a transoralis csoportban, míg egy esetben igazoltunk pneumoniát a transcervicalis csoportban. Az átlagos mútéti idő $(42,5$ versus [vs.] 98 perc, $\mathrm{p}<0,001)$, a per os táplálásig eltelt idő ( 2,9 vs. 4,6 nap, $\mathrm{p}<0,001)$ és az ápolási napok száma (7,3 vs. 9,7 nap, $p<0,001)$ is szignifikánsan rövidebb volt a transoralis csoportban, mint a transcervicalis csoportban. A kontrollvizsgálatok során 15 beteg teljesen panaszmentes volt. Transcervicalis eljárást követóen két esetben maradtak vissza panaszok (mérsékelt dysphagia, illetve tartós rekedtség). Transoralis mútét után 6 betegnél recidív tünetek jelentkeztek, 4 betegnél súlyos regurgitatio miatt transcervicalis mútétet végeztünk.

Köpetkeztetés: A transoralis stapler diverticulostomia gyors, rövid kórházi ápolást biztosító beavatkozás, mely elsősorban idős, komorbid betegeknél és közepes diverticulumméret esetében választandó. Hosszú távon a tartós regurgitatio miatt a betegek egy részénél ismételt beavatkozásra lehet szükség. A transcervicalis feltárás magasabb perioperatív morbiditással járó mútéti beavatkozás, melyet elsősorban a $3 \mathrm{~cm}$ alatti és nagy diverticulumméret fennállásakor javasolt végezni.

Orv Hetil. 2019; 160(16): 629-635.
\end{abstract}

Kulcsszavak: Zenker-diverticulum, összehasonlító vizsgálat, endoszkópos sebészet, transcervicalis diverticulectomia, stapler diverticulostomia

\section{A comparative study of short- and long-term outcomes for transcervical versus transoral surgery for Zenker diverticulum}

Introduction and aim: We present our experience with open (transcervical diverticulectomy, cricomyotomy) and transoral surgery (transoral stapler diverticulostomy) for Zenker diverticulums.

Method: Between 1 January 2006 and 31 December 2016, 29 patients were examined with a symptom-causing Zenker diverticulum. In 13 cases, transcervical surgery, in 16 cases, transoral surgery were performed. Perioperative and long-term results were evaluated and compared.

Results: Patients were operated on after an average of 31 months with complaints. In both groups, the leading symptoms were severe dysphagia and severe regurgitation. No intraoperative complication was detected. In the transoral group, one patient had to be reoperated on for bleeding, another patient developed pneumonia in the transcervical group. The average duration of the surgeries $(42.5$ versus [vs.] 98 minutes, $\mathrm{p}<0.001)$, the time to oral feeding $(2.9$ 
vs. 4.6 days, $\mathrm{p}<0.001)$ and the mean hospital stay ( 7.3 vs. 9.7 days, $\mathrm{p}<0.001)$ were significantly shorter in the transoral group than the transcervical group. 15 patients were completely symptomless postoperatively. After transcervical treatment, complaints were developed in 2 cases (moderate dysphagia and hoarseness). After transoral surgery, recurrent symptoms were observed in 6 patients, 4 had to be reoperated transcervically due to severe regurgitation. Conclusion: Transoral stapler diverticulostomy is a fast procedure and offers short hospital stay especially in comorbid, aged patients and intermedium diverticulum size. In the long term, some of the patients may require reintervention due to persistent regurgitation. The transcervical approach has higher perioperative morbidity, which can be performed in patients with less than $3 \mathrm{~cm}$ or large diverticulum size.

Keywords: Zenker diverticulum, comparative study, endoscopic surgical procedure, transcervical diverticulectomy, stapler diverticulostomy

Andrási L, Ábrahám Sz, Simonka Zs, Paszt A, Rovó L, Lázár Gy. [A comparative study of short- and long-term outcomes for transcervical versus transoral surgery for Zenker diverticulum]. Orv Hetil. 2019; 160(16): 629-635.

(Beérkezett: 2018. november 15.; elfogadva: 2018. november 30.)

\section{Rövidítések}

$\mathrm{BMI}=($ body mass index $)$ testtömegindex; FESD $=($ flexible endoscopic septum division) flexibilis endoszkópos septotomia; SZTE = Szegedi Tudományegyetem; TCD = transcervicalis diverticulectomia + cricomyotomia; TSD = transoralis stapler diverticulostomia

A nyelőcső pharyngooesophagealis vagy más néven Zenker-diverticulumai a nyelőcső pseudodiverticulumai, annak nyálkahártyáját és submucosalis rétegét tartalmazó kiöblösödések, melyek a hypopharynx hátsó falán, a musculus $(\mathrm{m}$.$) constrictor pharyngis inferior ferde és a$ m. cricopharyngeus harántrostjai között, az úgynevezett Killian-Laimer-háromszögben alakulnak ki. Az elváltozásokat pulziós jellegünek tartjuk, mivel az előbbi izomapparátus kóros múködése (spazmus, elégtelen relaxáció) következtében megemelkedik a pharyngooesophagealis intraluminalis nyomás. Bár a gurdély kialakulásának pontos eredete továbbra sem tisztázott, alapvetően két fontos tényező szerepelhet lehetséges okként: a kóros nyelőcső-motilitás és a nyaki nyelőcsőszakasz izomrétegének anatómiai elváltozása. Mindezek mellett egyértelmü összefüggést fedeztek fel a gastrooesophagealis reflux betegség és a Zenker-diverticulum kialakulása között, az egyfajta védekező reflexként kialakuló felső nyelőcsősphincter-nyomásfokozódás következményeként $[1,2]$.

A kórkép meglehetősen ritka, incidenciája mindösszesen 0,01-0,11\% között mérhető az átlagpopulációban; a prevalencia 0,06 és 4\% között változik az Amerikai Egyesült Államokban (USA). A Zenker-diverticulum ritkán jelenik meg 30 éves kor alatt, a betegek többsége 60 év feletti (65-75 év közötti csúccsal), 1,5-szeres férfidominancia mellett [3].

A tünetek széles skálán jelentkezhetnek, a legtöbbször dysphagia és ételregurgitatio formájában, de a diverticulumban pangó ételmaradék aspiratiója és a krónikus/re- kurráló pneumonia is gyakori tünet. Ritkábban gombócérzés, halitosis és odinophagia is szerepelhet panaszként.

A diverticulum konzervatív kezelésre nem tud meggyógyulni, az idő múlásával fokozatosan növekszik, és a beteg panaszai is szaporodnak, egyben a különböző szövődmények kialakulásának valószínúsége is emelkedik (aspiratio, aspiratiós pneumonia, perforáció, vérzés és a diverticulumban fellépő gyulladás). A kezelés sebészi, a hagyományos operatív megoldás a transcervicalisan végzett phrayngo-oesophagealis myotomiából és a diverticulum reszekciójából áll. Már több évtizede ismert az úgynevezett transoralis beavatkozás is, melynek lényege, hogy szájon át, (rigid vagy flexibilis) endoszkópot használva valamilyen szövetszétválasztó eszköz segítségével átvágjuk a diverticulum és a nyelőcső közös falát a felső nyelőcsősphincterrel együtt, aminek eredményeként közös lumen jön létre (oesophagodiverticulostomia). A szájadék képzéséhez a módszer első leírója, Mosher [4] 1917-ben még szikét használt, a későbbiekben jóval kevesebb szövődményt okozva elektromos kést [5] és szén-dioxid $\left(\mathrm{CO}_{2}\right)$-lézert vettek igénybe. A minimálisan invazív sebészet és a hozzá tartozó eszköztár megjelenése ezt a módszert is korszerűsítette. A Zenker-diverticulum gyógyításában az „endoszkópos-varrógépes” módszer is régóta ismert. Collard 1993-ban sikeresen használt endoszkópos varrógépet a diverticulostoma képzéséhez [6]. A varrógép nemcsak átvágja, hanem kapocssorok berakásával biztonságosan le is zárja a szájadék széleit, így csökkentve a sebészi szövődmények kialakulásának lehetőségét. Magyarországon először munkacsoportunk számolt be a módszer alkalmazásáról, mely elsősorban idős betegek esetén és $3 \mathrm{~cm}$-nél nagyobb Zenker-diverticulumok megszüntetésére javasolt [7].

Napjainkban a kezelési spektrum Zenker-diverticulum esetében is igen széles. A megközelítés lehet konvencionális (ferde nyaki metszésból) vagy transoralis. A transoralis megoldás rigid vagy flexibilis endoszkóppal is kivitelezhető, a közös fal átvágására is számos opció adott (elektromos kés, LigaSure [Valleylab, Boulder, CO, 
USA] endostapler, $\mathrm{CO}_{2}$-lézer). Az utóbbi lehetőségre az egyre bővülő minimálisan invazív eszköztár következtében egyre több centrum vállalkozik, az első közlemények 1995-ben jelentek meg Mulder és Ishioka munkacsoportjának tapasztalatairól [8, 9]. Kijelenthet”, hogy „arany standard"-eljárás nem létezik, azonban a beavatkozást végző munkacsoport tapasztalata meghatározó tényező.

Nagyon lényeges, hogy bármelyik terápiás lehetőséget választjuk is, az egyénre szabottan történjen, hiszen csak ebben az esetben érhető el tartósan jó posztoperatív funkció és tünetmentesség. Optimális mütétet csak a következő tényezők mérlegelése után végezhetünk: a beteg anatómiai sajátosságai, diverticulumméret és sebészi kockázat.

Retrospektív klinikai vizsgálatunkban ezért célul tûztük ki, hogy megvizsgáljuk a TCD (transcervicalis diverticulectomia, cricomyotomia) és a TSD (transoralis stapler diverticulostomia) eljárások perioperatív és hosszú távú eredményeit.

\section{Módszer és betegek}

A Szegedi Tudományegyetem Sebészeti Klinikáján 2006. január 1. és 2016. december 31. között 29 beteget (20 férfi, 9 nő, átlagéletkor: 66 év, 34-89) kezeltünk panaszokat okozó Zenker-diverticulum miatt. A TCDcsoport átlagéletkora 65,4 év (34-86) volt nagy férfidominancia mellett (12/1), a TSD-csoport átlagéletkora 68,2 év (47-89) volt egyenlő nemi eloszlásban (8/8). A leggyakoribb panasz a súlyos dysphagia (TCD-csoport: $\mathrm{n}=11,85 \%$, TSD-csoport: $\mathrm{n}=13,81 \%$ ) és a súlyos regurgitatio (TCD-csoport: $\mathrm{n}=10,77 \%$, TSD-csoport: $\mathrm{n}=11,69 \%)$ volt. A betegek kisebb arányban számoltak be rekedtségről, falatelakadásról, köhögésről és refluxos epizódokról. Jelentős mértékű fogyás a TSD-csoportban volt megfigyelhető $(25 \%, 4 / 16)$. A preoperatív kivizsgálás 47,7 mm-es (30-140) átlagos diverticulumméretet igazolt, mely a két csoportban csaknem megegyezett (TCD: 49 [30-120] mm, TSD: 46,6 [30-140] mm).

A panaszok fennállásának átlagos időtartama 31,7 hónap volt (3-240), csoportokra lebontva a TCD-nél 46 hónap (3-240 hónap), a TSD-nél 18,6 hónap (3-72 hónap). A betegek részletes anamnézisfelvételt követően komplex gasztroenterológiai kivizsgáláson estek át (kontrasztos nyelés-röntgenvizsgálat, felső tápcsatornai endoszkópia). A kimutatható gurdély mellett mind a TCD-, mind a TSD-csoportban 4-4 betegnél gyógyszeresen kezelt GERD (TCD: 30\%, TSD: $25 \%$ ) volt ismert. A kórtörténeteket áttekintve pneumoniát csak a TSDcsoportban, mindösszesen 1 beteg távoli anamnézisében találtunk $(6,2 \%)$.

\section{Sebészi kezelés}

Transcervicalis diverticulectomia és cricomyotomia történt 13 páciensnél. Transoralis stapler diverticulostomiát 16 alkalommal végeztünk. 4 esetben TSD után TCD- mütét történt. A nyitott mütét során eltávolított gurdélyokat kivétel nélkül szövettani vizsgálatra küldtük. A betegek per os táplálását negatív nyelésvizsgálatot követően fokozatosan építettük fel. Antibiotikumprofilaxisként harmadik generációs cefalosporint alkalmaztunk.

\section{Mütéti technika}

Transcervicalis diverticulectomia, cricomyotomia Intratrachealis narkózisban hanyatt fekvő helyzetben a beteg fejét jobb oldalra és hátrafelé fordítva rögzítettük. A diverticulum feltárását, reszekcióját, illetve a cricopharyngealis myotomiát a $\mathrm{m}$. sternocleidomastoideus medialis széle mentén vezetett ferde metszésből végeztük el. A diverticulumokat nyitott technika mellett egyenes varrógép (TX60 Linear Stapler, Ethicon Endo-Surgery Inc., Cincinnati, OH, USA) használatával reszekáltuk úgy, hogy varrás után ne maradjon vissza nyelőcsőszúkület. Ezt követően a myotomiát a diverticulum alsó szélétől a nyelőcsőre is ráterjedően, körülbelül 3-4 cm hoszszan készítettük el.

\section{Transoralis stapler diverticulostomia}

A mütét során intratrachealis narkózisban a hanyatt fekvő beteg fejét hátrahajtott, hiperextendált pozícióban rögzítettük. A hypopharynxot rigid, nyitható szárú laringoszkóp (Weerda, Karl Storz, Tuttlingen, Németország) segítségével tártuk fel. A direkt vizuális kontrollt $5 \mathrm{~mm}$-es endoszkópos kamerával biztosítjuk. Látótérbe hozzuk a nyelőcső és a diverticulum szájadékait. Az endostaplert (Endo-GIA $^{\mathrm{TM}}$ USSC, Norwalk, CT, USA, blue cartridge [45, illetve $60 \mathrm{~mm}$-es]) oly módon vezetjük be a hypopharynxba, hogy a nyelőcső és a diverticulum közös fala a varrógépszárak közé kerüljön. A varrógép elsütésével V alakú közös szájadékot képzünk a nyelőcső és a diverticulum között, és széleit 3-as kapocssorral zárjuk le.

A mütéteket követően vízoldékony kontrasztanyaggal (Gastrografin ${ }^{\circledR}$, diatrizoát-meglumin) végeztünk nyelésröntgenvizsgálatot.

\section{Utánkövetés}

A betegek $82,7 \%$-a $(24 / 29)$ jelentkezett mütétet követően egy hónappal sebészeti kontrollvizsgálatra. Az ellenőrző vizsgálatok során elemeztük a panaszok változását a mưtét előttiekhez viszonyítva, valamint szükség esetén a radiomorfológiai eltéréseket. Amennyiben a betegek a későbbiekben panaszossá váltak, soron kívüli kivizsgálást és szükség esetén kezelést végeztünk. Hosszú távú (átlagosan 86,1 hónap, 45-128) vizsgálatunkban a mütét eredményességét kívántuk felmérni a tünetek tükrében.

\section{Statisztika}

Az összes adatot Excel-táblázatban gyüjtöttük össze. A statisztikai elemzéshez a SigmaPlot (SigmaPlot, Win- 
dows-verzió: 12.5, 2011 Systat Software, Inc., San Jose, CA, USA) szoftvert használtuk. Mann-Whitney-tesztet alkalmaztunk, a $\mathrm{p}<0,05$ értéket tekintettük statisztikailag szignifikánsnak.

Vizsgálatunk a Szegedi Tudományegyetem SzentGyörgyi Albert Klinikai Központja Humán Orvosbiológiai Intézményi és Regionális Kutatásetikai Bizottságánakjóváhagyásával történt (iktatószám: 180/2017-SZTE, engedélyszám: 4396).

\section{Eredmények}

Minimális vérvesztés $(50-100 \mathrm{ml})$ mellett a mútéti idő átlagosan 70 perc volt (TCD-csoport: $98 \pm 62$ perc, TSD-csoport: $42,5 \pm 27,5$ perc; $\mathrm{p}<0,001)$. Intraoperatív szövődményt egyik csoportban sem észleltünk. A TSDcsoportban feltárási, illetve vizualizációs probléma miatt 2 betegnél hagyományos sebészi ellátás történt (15\%).

Vérzés miatt egy alkalommal reoperációt végeztünk a TSD-csoportban (1/16, 6\%), míg 1 betegnél igazoltunk pneumoniát a TCD-csoportban $(1 / 13,7 \%)$ (1. táblázat).

A posztoperatív szakban végzett kontroll-nyelésröntgenvizsgálat kóros eltérést egyik esetben sem igazolt. A betegek negatív képalkotó vizsgálatát követôen átlag 3,7 nap után (TCD: 4,6 $\pm 2,6$ nap, TSD: $2,9 \pm 2$ nap; $\mathrm{p}<0,001)$ fokozatosan építettük fel per os táplálkozásukat, és panaszmentesen bocsátottuk óket otthonukba. $\mathrm{Az}$ ápolási napok száma a TCD-csoportban átlagosan 9,7 (7-12) nap, a TSD-csoportban 7,3 (5-10) nap volt $(\mathrm{p}<0,001)$ (1. táblázat).

A diverticulumok szövettani vizsgálata egyik esetben sem mutatott dysplasiát, malignitást. Egy esetben sem észleltük a gépi varratsor elégtelenségét $(0 / 29,0 \%)$, perioperatív mortalitás nem fordult elő. Az egy hónapos kontrollvizsgálat során a betegek 62,5\%-a (15/24) teljesen panaszmentes volt.

Késői utánkövetés után a betegek életminősége jelentősen javult, a mütét előtt kimutatott súlyos fokú, elsősorban dysphagiás és regurgitatióval összefüggő tüneteik minimálisra csökkentek vagy teljesen megszűntek. A TSD-csoportban a felülvizsgálatra érkezett betegek felénél $(6 / 12,50 \%)$ találtunk recidív panaszt, 4 esetben (4/12, 33\%) nyaki mütétre került sor a későbbiekben. $\mathrm{Az}$ ismételt beavatkozásra kerülő betegek fó panasza súlyos regurgitatio $(2 / 4)$, súlyos dysphagia (1/4) és egy esetben a két panasz együttes jelenléte $(1 / 4)$ volt. Közülük 3 betegnél a panaszok fél évvel a primer mútét után jelentkeztek, míg a 4 . esetében 4 évvel utána (2. táblázat).

A TSD-csoportban egy betegnek $(6,2 \%)$ a súlyos dysphagiája megszûnt, de időnként regurgitatióról számol be, míg egy másiknak mérsékelt nyelészavara alakult ki $(6,2 \%)$. Az ismételt beavatkozást (TCD) igénylő betegeknél 1 esetben a transcervicalis beavatkozás után egy hónappal nyaki tályog alakult ki; a sebészi feltárást követően a páciens állapota fokozatosan javult, jelenleg pa-
1. táblázat | Perioperatív eredmények TSD-t és TCD-t követően

\begin{tabular}{lccc}
\hline & TSD & TCD & Statisztika \\
\hline Nem $(\mathrm{N} / \mathrm{F})$ & $8 / 8$ & $1 / 12$ & \\
Életkor (év) & 68,2 & 65,4 & \\
& $(47-89)$ & $(34-86)$ & \\
Diverticulumméret (mm) & $46,6(30-140)$ & $49(30-120)$ & \\
Mütéti idő (perc) & $42,5(15-70)$ & $98(36-160)$ & $\mathrm{p}<0,001$ \\
$\begin{array}{l}\text { Feltárási sikertelenség } \\
\text { (n [\%]) }\end{array}$ & $2(15)$ & & \\
$\begin{array}{l}\text { Varratelégtelenség (n) } \\
\text { Reoperációt igénylő }\end{array}$ & $1($ vérzés $)$ & & \\
szövódmény (n) & & & \\
$\begin{array}{l}\text { Mortalitás (n) } \\
\text { A per os táplálás kezdete } \\
\text { (nap) }\end{array}$ & $2,9(1-7)$ & $4,6(3-7)$ & $\mathrm{p}<0,001$ \\
Ápolási napok száma & $7,3(5-10)$ & $9,7(7-12)$ & $\mathrm{p}<0,001$ \\
\hline
\end{tabular}

TCD = transcervicalis diverticulectomia + cricomyotomia; TSD = transoralis stapler diverticulostomia

2. táblázat | Ismételt beavatkozást igénylő betegek $(\mathrm{n}=4)$

\begin{tabular}{|c|c|c|c|c|}
\hline Első mütét & $\begin{array}{l}\text { Második } \\
\text { mútét }\end{array}$ & $\begin{array}{l}\text { A mútétek } \\
\text { között eltelt } \\
\text { idő (hónap) }\end{array}$ & Panaszok & $\begin{array}{l}\text { A panaszok } \\
\text { visszatérése } \\
\text { az első mütét } \\
\text { után (hónap) }\end{array}$ \\
\hline TSD & TCD & 96 & $\begin{array}{l}\text { Dysphagia + } \\
\text { Regurgitatio }\end{array}$ & 48 \\
\hline TSD & TCD & 9 & Regurgitatio & 6 \\
\hline TSD & TCD & 10 & Regurgitatio & 6 \\
\hline TSD & TCD & 84 & Dysphagia & 6 \\
\hline
\end{tabular}

$\mathrm{TCD}=$ transcervicalis diverticulectomia + cricomyotomia; TSD = transoralis stapler diverticulostomia

naszmentes, nyelésfunkciója megtartott. A további 3 reintervenciós beteg teljesen panaszmentes.

A TCD-csoportban kielégítő nyelésfunkció mellett egy betegnek tartós rekedtsége alakult ki $(5,8 \%)$, míg egy másiknál $(5,8 \%)$ a súlyos regurgitatio megszúnt, viszont mérsékelt dysphagia jelentkezett.

\section{Megbeszélés}

Az általunk is alkalmazott mindkét sebészi beavatkozás (TSD, TCD) az irodalmi adatokkal megegyezően alacsony morbitással járó és kielégítő hosszú távú eredményeket biztosító eljárás. Jelen vizsgálatunkban haláleset nem fordult elő, egy-egy esetben észleltünk jelentősebb posztoperatív morbiditást: egy reoperáció történt vérzés miatt, illetve egy pneumonia alakult ki.

A TSD-mütét szignifikánsan rövidebb ideig tartott, és a per os táplálást is hamarabb kezdhettük meg, az utánkövetés során azonban recidív/residualis panaszok jelentkeztek, melyek miatt 4 alkalommal nyitott mútét vált 
szükségessé. A TCD-csoportban recidív panaszok miatti reoperáció nem fordult elő. A TCD-csoportban azonban egy betegnél alakult ki tartós rekedtség, melynek oka feltehetően a feltárással összefüggő nervus (n.) recurrens laesio lehetett.

A Zenker-diverticulum sebészi kezelése esetén 4 alapvetô kérdés mindenképpen megbeszélést igényel: a diverticulum mérete, a beteg életkora, a cricomyotomia kérdésköre és a helyes feltárás megválasztása.

A $2 \mathrm{~cm}$ alatti Zenker-diverticulumok kezelési stratégiáját a cricomyotomia határozza meg, reszekcióra nincs szükség. A transoralis behatolásból végzett stapler diverticulostomia után gyakran látható residualis közös szájadék a nyelő́ső és a diverticulum között, mely állapot kapcsán felvetődhet a kérdés: milyen gurdélynagyság esetében optimális a szájon át történő terápia? Ozgursoy és munkacsoportja a 3-6 cm közötti elváltozások esetében javasolja a transoralis mútéteket [10]. Egyetértve az irodalommal, a mi megfigyelésünk is azt mutatja, hogy az előretörő minimálisan invazív éra előnyei ellenére a 2 $\mathrm{cm}$ alatti és a $6 \mathrm{~cm}$ fölötti diverticulummérettel észlelt betegek nem profitálnak az endoszkópos terápiából. Mindez azzal magyarázható, hogy kicsi diverticulumnál a septotomia nem elégséges, míg a nagyobbak esetében tömegesebb septumot kell átvágni, ami potenciális veszélyeket rejt: nagy energiájú vágóeszközöknél magasabb vérzéses komplikációkat, varrógépes megoldások után nagyobb varratelégtelenségi arányt mutattak ki, hosszú távon pedig a betegek egy részénél a residualis gurdély regurgitatiót okozhat [11, 12].

A műtétek eltérő megközelítésétől függetlenül, az idó elörehaladtával egy koncepció nem változott: a m. cricopharyngeus múködési zavarán alapul a Zenker-diverticulum kialakulása, ezért ennek myotomiája kulcsfontosságú [13]. Korábbi vizsgálatok a gurdélyok ismételt kifejlődésének okát egyértelmúen a myotomia hiányára vezették vissza [14].

A nyitott mútét azonban fokozott kockázatot jelenthet a hosszabb mútéti és felépülési idő miatt. Mivel a Zenker-diverticulum föleg az idősebb, 70 év feletti populációban fordul elő gyakrabban, e betegcsoport tagjai a legtöbbször krónikus betegségekben szenvednek, általános állapotuk rosszabb, ezért a sebészi kockázat mérséklése kiemelt jelentőségú. Mindezekre tekintettel a kisebb teherbíró képességú betegek számára a transoralis (rigid vagy flexibilis endoszkópos) behatolás ideális megoldás lehet. A rövidebb kórházi tartózkodás, a gyorsabb felépülési idő és a per os fogyasztás hamarabbi elkezdése $[15,16]$ mellett a szövődmények előfordulása és a perioperatív mortalitás is általánosságban véve kedvezőbb a transoralis csoportban: a korábban közölt 3\%-os intraoperatív mortalitási mutatókat megjavítva Verdonck öszszesített adatai szerint a nyitott technika $0,9 \%$-os, a transoralis $0,4 \%$-os értékeket jelzett; ugyanezen jellemzők Yuan vizsgálatában $0,6 \%$ és $0,2 \%$ voltak $[9,17]$.

A lehetséges komplikációk a megközelítési módoknak megfelelően nyilvánvalóan eltéróek lehetnek. A transora- lis/endoszkópos csoportban a leggyakoribb a mediastinitis ( $1,2 \%$ vs. $<0,3 \%)$ és a nyaki emphysema $(3,0 \%$ vs. $<0,1 \%)$, míg a nyitott csoportban fistula $(3,7 \%$ vs. $1,2 \%)$ és a n. recurrens sérülése $(3,4 \%$ vs. $<0,3 \%)$ fordul elő többször.

Az endoszkópos terápia hátrányaként a feltárási nehézségeket és a kiújuló panaszokat kell megemlíteni. Nem megfelelő feltárást 30\%-ban közölnek az összefoglaló tanulmányok, ugyanakkor a legnagyobb egycentrumos, Wilken és munkacsoportja által végzett, 337 beteget számláló endoszkópos publikáció 3,9\%-os eredményt igazolt [18]. Köztudott, hogy a kisebb diverticulumméret kevésbé hatékony endoszkópos sikerrel társul, bár Wilken elemzése ezt a megállapítást nem erősítette meg, míg egy közelmúltbeli összehasonlító vizsgálat 39\%-os endoszkópos recidíváról számol be [19].

A sikertelen megközelítés következménye inkomplett diverticulostomia és az izomapparátus elégtelen átvágása, ami felelős lehet a perzisztáló/kiújuló panaszokért. Jól ismert a myotomia komplettsége, legyen az nyitott vagy endoszkópos út, így a standard sebészi megoldás elengedhetetlen része.

Verdonck munkacsoportjának eredményeihez visszakanyarodva az összesített sikertelenségi arány endoszkópia esetében $18,4 \%$, nyitott mód alkalmával $4,2 \%$ volt, mely magában foglalja a rövid távú sikertelenséget (insufficiens feltárást) és a korai recidívákat is. Külön vizsgálva a rövid távú sikerességet, a nyitott megoldás mutatkozott előnyösebbnek (endoszkópos: 9,3\% vs. nyitott: 1,3\%). Egy másik tanulmány szerint 5,2\%-os endoszkópos feltárási nehézségek mellett, hosszú távon a nyitott metódusnál 2,9\%, endoszkópiánál 3,9\%-os késői kiújulási arányt igazoltak [16]. Saját gyakorlatunkban a TSD-csoportban összesen 2 betegnél lépett fel vizualizációs probléma, mely miatt hagyományos (transcervicalis) sebészi ellátás történt (15\%).

Jelen klinikai vizsgálatunkban a betegek szájon át való táplálását rendelkezésre álló, negatív képalkotó diagnosztikával kívántuk elkezdeni. Munkacsoportunk TCD-nél átlagosan 4 nap, TSD-nél 2 nap után végzett nyelés-röntgenvizsgálatot vízoldékony kontrasztanyaggal, minden esetben negatív eredménnyel.

A TSD-módszer gyors és technikailag egyszerúen kivitelezhetô beavatkozás, azonban nem mindig tökéletes választás, hiszen a sikertelenség forrásai lehetnek a beteg anatómiai-alkati jellemzői (nem kellően extendálható nyak, degeneratív musculoskeletalis betegségek, az elégtelen szájnyitás következtében kialakult vizualizációs nehézségek) és a diverticulum paraméterei $(3 \mathrm{~cm}$ alatti diverticulum, a diverticulum és a nyelőcső közötti septum rövidsége, $6 \mathrm{~cm}$ fölötti diverticulum). A kicsi septumból fakadó problémák kiküszöbölésére számos technikai újítás, múfogás terjedt el (például a septumba helyezett úgynevezett „húzó öltés” vagy a septum nyálkahártyájának elővágása a varrógép pozicionálása előtt), melyek választható opciót jelenthetnek a konverzió mellett [20]. Léteznek olyan, főleg az aneszteziológiában használatos 
paraméterek, melyek antropometriás számítások után prognosztikus jelentőséggel bírnak az adott módszer sikeressége vagy éppen sikertelensége szempontjából (szájnyitás mm-ben kifejezve, BMI, thyromentalis távolság, Mallampati- és Cormack-pontok).

A nyitott és rigid endoszkópiával végzett eljárásokkal együtt feltétlenül meg kell említeni a flexibilis endoszkópia által nyújtott alternatívát is. A negatív tényezők kiküszöbölésére teret nyert a flexibilis endoszkópia alkalmazása $[8,9]$, miközben a minimálisan invazív technika nyújtotta előnyök nem csorbultak. A flexibilis endoszkópia a rigid endoszkópia alapját megőrzi, nevezetesen, a septum átvágásával közös lument hoz létre, egyben automatikusan a myotomiát is elvégzi. Következetesen a beavatkozást hivatalosan flexibilis endoszkópos septotomiának nevezik (angol nyelvterületen: flexible endoscopic septum division, röviden FESD), és a magas kockázatú idős betegek profitálnak belőle a leginkább [21]. A beavatkozás fekvőbeteg-ellátásban, illetve ambuláns keretek között is elvégezhető, nem különösebben igényel érzéstelenítést, gyors és hatékony [22]. Néhány centrum egyenesen az összes Zenker-diverticulumos betegnek ezt az opciót ajánlja fel, de a legtöbb szerző egyetért abban, hogy a módszer inkább azon úgynevezett „high-risk” betegekre tartogatható, akiknél a feji és nyaki anatómiai sajátosságok nem teszik lehetővé a rigid endoszkópia elvégzését [23]. Napjainkban már a hazai gyakorlatban is elérhető a flexibilis endoszkópos beavatkozás, Gyökeres és munkacsoportja 30 intervenciót (köztük 6 reintervenciót) végzett 5 év alatt, az irodalmi adatokkal megegyező szövődmény- és kiújulási rátával [24]. A flexibilis technika lehet szabad kézi, illetve számos kiegészítővel kombinált, melyek a kívánt pozíció megtalálásában és megtartásában, végső soron a korrekt kivitelezésben nyújtanak segítséget. Ilyen az úgynevezett „transparent cap” technika, mely jobb feltárást tesz lehetővé, illetve kifejezetten a Zenker-diverticulumhoz elérhető egy úgynevezett divertikuloszkóp is (ZD overtube; Cook Endoscopy, Winston-Salem, NC, USA), mely kialakításából adódóan védelmet kölcsönöz a nyelőcső elülső falának és a diverticulum hátulsó falának is. Az átvágási technikák a rigid módszerhez hasonlatosak. A mikroperforációk és a következményes mediastinitisek megelőzésére néhány munkacsoportnál elterjedt az úgynevezett klipasszisztált technika, melynek során az átvágandó területre a mozzanat előtt klipet helyeznek fel. A flexibilis endoszkópiát és az endostaplert összehasonlító vizsgálatok hasonló eredményekről számolnak be a kórházi tartózkodás, a tünetek javulása és a komplikációk előfordulása terén, azonban a beavatkozás időtartama az endostaplercsoportban hosszabb. A klinikai hatékonyság tekintetében a flexibilis endoszkópia változatos képet mutat a maga 56-100\%-os sikerességi arányával, ami a dsyphagia javulására lebontva 84-100\%-ot ért el [6, 7, 23]. A flexibilis endoszkópia alkalmazásával körülbelül 20\%-os kiújulás várható a jelenlegi irodalmi adatok alapján [21].
A kiújulás prediktorai az alábbi tényezők lehetnek: kezelés előtti diverticulumméret $>5 \mathrm{~cm}$, kezelés utáni diverticulumméret $>1 \mathrm{~cm}$, a septotomia hossza $<2,5 \mathrm{~cm}$. Antonello és munkacsoportja sikeresen bizonyította a flexibilis endoszkópia hatékonyságát mind nyitott, mind rigid endoszkópos eljárások után kiújult gurdélyok esetében, mivel 84\%-os teljes panaszmentességet értek el a vizsgált betegcsoportban [26]. Az eljárás szövődményei között említést érdemel a perforáció következtében kialakult nyaki tályog/mediastinitis $(0-27 \%)$ és a vérzés (0-10\%) [23].

A prospektív, randomizált, különböző intervenciókat összehasonlító tanulmányok hiányoznak az irodalomból; a számításba vett publikációk retrospektívek, és számos bizonytalan paramétert tartalmaznak. Mindezek ellenére látható, hogy mind az endoszkópos, mind a nyitott megoldás túlnyomórészt enyhít a panaszokon, és biztonságosak. Mindezek mellett szükséges az adott technika elemzése a hosszú távú nyelésfunkció tekintetében [27]. Az utóbbi munkacsoport vizsgálata szerint a nyitott csoport betegeinél jobb hosszú távú panaszmentességet lehetett elérni.

Vita tárgyát képezi az a felvetés, miszerint könnyebb elvégezni egy endoszkópos terápiát, mint egy hagyományos feltárást (hacsak nem nyelőcsőközpontban történik a beavatkozás), ezért nehéz kijelenteni azt, hogy nem az endoszkópos megoldás az első választandó, míg korlátozott feltárás, reoperáció esetén a nyitott út az előnyösebb. Előzőleg nyakon végzett mütétek, a betegek rossz általános állapota, előrehaladott életkora, a várhatóan kevesebb mútéti idő és megterhelés az endoszkópia felé billentik a mútét típusának megválasztását. Nyitott mód javasolt a fiatal, jó általános állapotú pácienseknél, a bizonyítottan jobb tartós eredmények és az alacsony valószínúségü korrekciós mûtét miatt [28]. Bármi legyen is a beavatkozás módja, a sebész tapasztalata és a beteg preferenciája meghatározó az optimális eljárás megválasztásakor.

Jelen vizsgálatunk során mindkét csoport betegei körében javult a nyelésfunkció. A posztoperatív nyelésfunkciót firtató eredményeink azt bizonyítják, hogy a transoralis eljárások után nagy százalékban maradnak vissza panaszok, melyeket egy újabb, lehetőleg nyitott mútéttel kell korrigálni.

Saját vizsgálatunkban igazoltuk, hogy betegeink fö panaszai a súlyos és rendszeres dysphagia és regurgitatio voltak, melyek a TCD-mütétet követően csaknem teljesen eltüntek. A TSD-csoportban a permanens panaszok miatt $4(4 / 29,13,7 \%)$ esetben újabb mútétre kényszerültünk, és az alkalmazott transcervicalis diverticulumreszekció és cricomyotomia teljes tünetmentességet eredményezett.

\section{Következtetés}

Álláspontunk szerint mindkét megközelítésből (TCD és TSD) végzett mütét biztonságos eljárás. A transoralis megoldás rendelkezik mindazon előnyökkel, melyeket a 
minimális invazív mütétek biztosítanak, azonban elsősorban a közepes $(3-6 \mathrm{~cm})$ diverticulumméret esetén optimális. A beavatkozások után az életminőség hosszú távú jelentős javulását várhatjuk, a betegek egy részénél azonban a panaszok kiújulhatnak.

Anyagi támogatás: A közlemény megírása, illetve a kapcsolódó kutatómunka anyagi támogatásban nem részesült.

Szerzői munkamegosztás: A szerzők a két eltérő mütéti technika korrekt kivitelezéséhez járultak hozzá operatőrként/kezelőorvosként (L. Gy., R. L., P. A.), illetve a beavatkozásnál asszisztáltak rendszeresen (S. Zs., Á. Sz., A. L.). Emellett a mütéten átesett betegek rövid és hoszszú távú sebészi eredményeit mérték fel (S. Zs., Á. Sz., A. L.). A cikk végleges változatát valamennyi szerző elolvasta és jóváhagyta.

Érdekeltségek: A szerzőknek nincsenek érdekeltségeik.

\section{Irodalom}

[1] Sasaki CT, Ross DA, Hundal J. Association between Zenker diverticulum and gastroesophageal reflux disease: development of a working hypothesis. Am J Med. 2003; 115(Suppl 3A): 169S$171 S$.

[2] Horváth ÖP, Bognár L, Papp A, et al. Esophageal complications of gastroesophageal reflux disease: consequences or defensive reactions? [A gastrooesophagealis refluxbetegség nyelöcsőszövődményei: következmények vagy védekezőreakciók?] Orv Hetil. 2017; 158: 763-769. [Hungarian]

[3] Watemberg S, Landau O, Avrahami R. Zenker's diverticulum: reappraisal. Am J Gastroenterol. 1996; 91: 1494-1498.

[4] Mosher H. Webs and pouches of the oesophagus, their diagnosis and treatment. Surg Gynecol Obstet. 1917; 25: 175-187.

[5] Dohlman G, Mattsson O. The endoscopic operation for hypopharyngeal diverticula: a roentgencinematographic study. AMA Arch Otolaryngol. 1960; 71: 744-752.

[6] Collard JM, Otte JB, Kestens PJ. Endoscopic stapling technique of esophagodiverticulostomy for Zenker's diverticulum. Ann Thorac Surg. 1993; 56: 573-576.

[7] Lázár G, Rovó L, Szentpáli K, et al. Endoscopic stapling diverticulostomy for Zenker diverticulum. [Endoszkópos varrógéppel képzett diverticulostoma a Zenker-diverticulum kezelésére.] Orv Hetil. 2004; 145: 15-17. [Hungarian]

[8] Mulder CJ, den Hartog G, Robijn RJ, et al. Flexible endoscopic treatment of Zenker's diverticulum: a new approach. Endoscopy $1995 ; 27: 438-442$.

[9] Ishioka S, Sakai P, Maluf Filho F, et al. Endoscopic incision of Zenker's diverticula. Endoscopy 1995; 27: 433-437.

[10] Ozgursoy OB, Salassa JR. Functional and manofluorographic outcomes after transoral endoscopic pharyngoesophageal diverticulostomy. Arch Otolaryngol Head Neck Surg. 2010; 136: 463-467.

[11] Yuan Y, Zhao YF, Hu Y, et al. Surgical treatment of Zenker's diverticulum. Dig Surg. 2013; 30: 207-218.
[12] Chang CY, Payyapilli RJ, Scher RL, et al. Endoscopic staple diverticulostomy for Zenker's diverticulum: review of literature and experience in 159 consecutive cases. Laryngoscope 2003; 113: 957-965.

[13] Yip HT, Leonard R, Kendall KA. Cricopharyngeal myotomy normalizes the opening size of the upper esophageal sphincter in cricopharyngeal dysfunction. Laryngoscope 2006; 116: 93-96.

[14] Skinner KA, Zuckerbraun L. Recurrent Zenker's diverticulum: treatment with crycopharyngeal myotomy. Am Surg. 1998; 64: 192-195.

[15] Leibowitz JM, Fundakowski CE, Abouyared M, et al. Surgical techniques for Zenker's diverticulum: a comparative analysis. Otolaryngol Head Neck Surg. 2014; 151: 52-58.

[16] Chang CW, Burkey BB, Netterville JL, et al. Carbon dioxide laser endoscopic diverticulotomy versus open diverticulectomy for Zenker's diverticulum. Laryngoscope 2004; 114: 519-527.

[17] Verdonck J, Morton RP. Systematic review on treatment of Zenker's diverticulum. Eur Arch Otorhinolaryngol. 2015; 272: 3095-3107.

[18] Wilken R, Whited C, Scher RL. Endoscopic staple diverticulostomy for Zenker's diverticulum: review of experience in 337 cases. Ann Otol Rhinol Laryngol. 2015; 124: 21-29.

[19] Shahawy S, Janisiewicz AM, Annino D, et al. A comparative study of outcomes for endoscopic diverticulotomy versus external diverticulectomy. Otolaryngol Head Neck Surg. 2014; 151: 646-651.

[20] Bonavina L, Rottoli M, Bona D, et al. Transoral stapling for Zenker diverticulum: effect of the traction suture-assisted technique on long-term outcomes. Surg Endosc. 2012; 26: 28562861.

[21] Ferreira LE, Simmons DT, Baron TH. Zenker's diverticula: pathophysiology, clinical presentation, and flexible endoscopic management. Dis Esophagus 2008; 21: 1-8.

[22] Case DJ, Baron TH. Flexible endoscopic management of Zenker diverticulum: the Mayo Clinic experience. Mayo Clin Proc. 2010; 85: 719-722.

[23] Dzeletovic I, Ekbom DC, Baron TH. Flexible endoscopic and surgical management of Zenker's diverticulum. Expert Rev Gastroenterol Hepatol. 2012; 6: 449-466.

[24] Gyökeres T. Endoscopic treatment of Zenker diverticulum. [Zenker-diverticulum endoszkópos kezelése.] ESGE Days 2018, Budapest, 2018. április 19. [Kongresszusi előadás] [Hungarian]

[25] Mulder CJ, Costamagna G, Sakai P. Zenker's diverticulum: treatment using a flexible endoscope. Endoscopy 2001; 33: 991-997.

[26] Antonello A, Ishaq S, Zanatta L, et al. The role of flexible endotherapy for the treatment of recurrent Zenker's diverticula after surgery and endoscopic stapling. Surg Endosc. 2016; 30: 23512357.

[27] Seth R, Rajasekaran K, Lee WT, et al. Patient, reported outcomes in endoscopic and open transcervical treatment for Zenker's diverticulum. Laryngoscope 2014; 124: 119-125.

[28] Johnson CM, Postma GN. Zenker diverticulum - which surgical approach is superior? JAMA Otolaryngol Head Neck Surg. 2016; 142: 401-403.

(Lázár György dr., Szeged, Semmelweis u. 8., 6720 e-mail: lg@surg.szote.u-szeged.hu)

A cikk a Creative Commons Attribution 4.0 International License (https://creativecommons.org/licenses/by/4.0/) feltételei szerint publikált Open Access közlemény, melynek szellemében a cikk bármilyen médiumban szabadon felhasználható, megosztható és újraközölhető, feltéve, hogy az eredeti szerző és a közlés helye, illetve a CC License linkje és az esetlegesen végrehajtott módositások feltüntetésre kerülnek. (SID_1) 